\title{
Histone-Lysine N-Methyltransferase KMT5C
}

National Cancer Institute

\section{Source}

National Cancer Institute. Histone-Lysine N-Methyltransferase KMT5C. NCI Thesaurus. Code C73700.

Histone-lysine N-methyltransferase SUV420H2 (462 aa, $~ 52 \mathrm{kDa}$ ) is encoded by the human SUV420H2 gene. This soluble, nuclear protein may play a role in repression of transcription by RNA polymerase II, and in establishment of pericentric heterochromatin domains. 